\title{
Geohazard Risk Management on Geotourism, Case Study: Pindul Cave, Gunung Kidul - Yogyakarta
}

\author{
Nurakhmi Qadaryati*, Yonas Rio Pambudi and Tri Winarno \\ Geological Engineering Department Universitas Diponegoro, Indonesia
}

\begin{abstract}
The geodiversity of Indonesia as an archipelago country has contributed huge benefits to the development of geotourism. One of them is featured as Pindul Cave geosite in Gunung Kidul Yogyakarta, which is already running as a well-known tourism site within the Gunung Sewu Geopark. In order to create a sustainable geotourism, it is necessary to have a good hazard risk management, especially regarding to geohazards. Since Pindul Cave has not prepared the management yet, this study aims to assess the variables in the geosite, this includes the likelihood and consequences, that will provide a holistic risk management plan. The highest geohazard risk comes from floods and landslides on the geosite. The assessment result mentioned that Pindul Cave Geosite is included in the High-Extreme category, which means that geosite needs immediate repairing action and even requires a specific plan on the managerial level in terms of handling and emergency conditions. In dealing with such risks, it is necessary to have engineering, administrative control, and procurement of personal protective equipment (PPE).
\end{abstract}

Keywords: Geotourism, sustainable, Pindul Cave, geohazard, risk management

\section{Introduction}

Geotourism is one of the tourism sectors that is focusing on the landscape and geological features, which relies on three pillars, geodiversity; biodiversity; and cultural diversity (Dowling, 2011 in Kubalikova, 2013; Rosana et.al, 2016). The geodiversity of Indonesia as an archipelago country has contributed huge benefits to the development of geotourism. One of it is featured as Pindul Cave geosite in Gunung Kidul Yogyakarta, that is already running as a well-known tourism site within the Gunung Sewu Geopark, where it has also been managed by the local government (Suyono, 2019).

Pindul Cave is a product of karstification. With water filling the cave throughout the year (underwater stream), it has become an attraction for tourists to experience the tubing activity. Hence, the number of tourists per year is significantly high in the last 5 years, even the foreign tourists begin to visit the site in 2016 and the number is rising ever since (Table 1). In terms of economic development, this condition gains a favorable value. On the other hand, the higher number of tourists will contribute high risk when a hazard happened.

Table 1 Number of tourist arrival to Pindul Cave in 2015-2019 (Dinas Pariwisata DIY, 2019; 2018;2017; 2016; 2015)

\begin{tabular}{llll}
\hline \multirow{2}{*}{ Year } & Tourist & & \\
\cline { 2 - 4 } & Local & Foreign & Total \\
\hline 2015 & 143.553 & - & 143.553 \\
\hline 2016 & 173.302 & 795 & 174.097 \\
\hline 2017 & 142.550 & 2.531 & 145.081 \\
\hline 2018 & 112.541 & 2.070 & 114.611 \\
\hline 2019 & 134.420 & 1.610 & 136.030 \\
\hline
\end{tabular}

In order to create a sustainable geotourism, assessments are not only conducted at the beginning of the establishment of a geosite, but it is required gradually even when the geosite already run as a geotourism activity. One of the aspects that is assessed in many assessment methods is the risk of hazards, both caused by 
nature and human activity (Pralong \& Reynard, 2005; Pereira et.al, 2007; Kubaliková, 2013). Hence, a good hazard risk management, especially regarding geohazards. Since Pindul Cave has not prepared the management yet, this study aims to assess the variables in the geosite, this includes the likelihood and consequences of the geohazards, that will provide a holistic risk management plan. The management staff and the geopark community, can make great use on the result of this research to establish a risk management plan, while the government may use it to design a suitable policy for Pindul Cave management and conservation.

\section{Pindul Cave}

Administratively, Pindul Cave is located in Bejiharjo of Gunung Kidul (Figure 1). It has also been mentioned previously that Pindul cave is one of the geosite within Gunung Sewu Geopark, specifically in the West Section, along with another six geosites (Parno, 2018). The cave itself is 198.59 in total length, maximum depth at $18 \mathrm{~m}$ below the entrance level, with $5 \mathrm{~m}$ average depth. Pindul Cave is also divided into 3 zones based on the light intensity, that are the light zone, dark zone, and dusk zone.

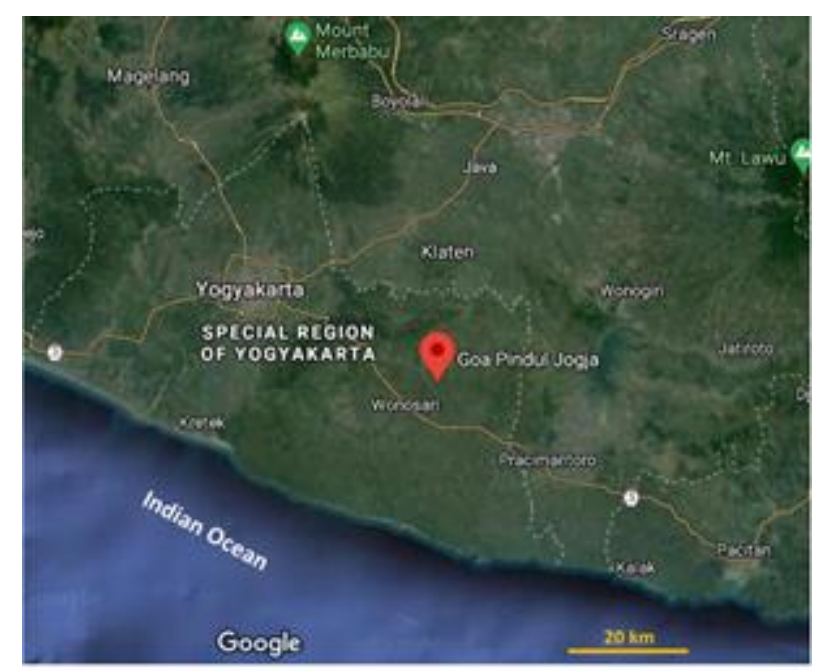

Figure 1. Location of Goa Pindul, administratively within Gunung Kidul area.

This research has also listed the potentials of Pindul Cave, referring to the Kubalikova (2013) geosite measurement technique. Regarding the scientific and intrinsic value, Pindul Cave geosite has the geoheritage that is highly valuable to the science world, because it provides evidence of karstification and also outcrops of Wonosari-Punung Formation within the area. The exemplarity and pedagogical potential of this geosite are captured by the locals, that they build motels, diner, and shopping corners for tourists that are looking for merchandise. The conservation is something that is primary geotuourism, but unfortunately, there was no policies powerful enough to guarantee the conservation of the cave geoheritage.

The accessibility is considerably easy, which is supported by road access (accessible by large buses) from several routes. Whilst the site infrastructure only consists of public facilitation, with insufficient signs about the educational or scientific information about the geoheritage.

The tourism activity provided by the Pindul Cave is that the tourists will travel through the cave by riding on a tube made from recycled truck tires. This activity highly dependent on the weather, because it will control the water level inside the cave. Inside the cave, the tourists enjoy the display of various cave morphology, such as stalactites, stalagmite, and flow stone. 


\section{Methods}

\section{Field Observation}

The hazard that can possibly happen in the geosite is caused both due to natural events and human activity. Field observation regarding the geological feature is one way to map the parameter and variables that contributed to the geohazard risk in Pindul Cave. The observation covers the area of $3 \times 3 \mathrm{~km}$, which includes the geological (determination of lithology and geological structure features) and geomorphological aspects.

\section{Risk Analysis}

In order to measure the risk in Pindul Cave, this research is conducting a risk analysis based on the Australian Standard/ New Zealand Standard 4360 (1995). The measurement is projected in a matrix (Table 2) that requires the parameter of the likelihood and consequences. The criteria of the likelihood parameter are shown in Table 3, while the consequences parameter is in Table 4.

Table 2 Coding the matrix based on the level of risk (modified from Standards New Zealand, 2004).

\begin{tabular}{|c|c|c|c|c|c|}
\hline \multirow[b]{2}{*}{ Likelihood } & \multicolumn{5}{|c|}{ Consequences } \\
\hline & 1 & 2 & 3 & 4 & 5 \\
\hline A & S & S & $\mathrm{E}$ & $\mathrm{E}$ & $\mathrm{E}$ \\
\hline B & M & S & S & $\mathrm{E}$ & $\mathrm{E}$ \\
\hline $\mathrm{C}$ & $\mathrm{L}$ & M & $S$ & $\mathrm{E}$ & $\mathrm{E}$ \\
\hline D & $\mathrm{L}$ & $\mathrm{L}$ & M & $\mathrm{S}$ & $\mathrm{E}$ \\
\hline $\mathrm{E}$ & $\mathrm{L}$ & $\mathrm{L}$ & $\mathrm{M}$ & $S$ & $S$ \\
\hline
\end{tabular}

$\mathrm{E}=\quad$ extreme- requires special planning at the top management level, and immediate handling / emergency conditions.

$\mathrm{S}=\quad$ significant- requires management's attention and takes corrective action as quickly as possible.

$\mathrm{M}=\quad$ moderate- does not involve top management, however, action should be taken immediately for handling/non-emergency conditions

$\mathrm{L}=\quad$ low- risk is sufficiently handled by the applicable routine procedures.

\section{Result and Discussion}

\section{Geological Aspects}

Based on the field observation, there are 2 lithological units, rudstone and grainstone, that composed the research area. The megascopic characteristic of rudstone is gray and has grain size $>5 \mathrm{~mm}$. Under the microscopic observation, it is composed of abundant skeletal grains from foraminifera (Figure 2) and algae, also nonskeletal grains of quartz. The petrographic observation result has also given the name to this unit, rudstone.

Based on the outcrop description, grainstone also has grey color but with finer grain size $(>2 \mathrm{~mm})$. Where through the petrographical analysis, it is consist of skeletal grains from foraminifera and algaes, also nonskeletal grains of quartz. The grains are less abundant than the previous facies, but still shows contact to each other (Figure 3). Dolomite is found as well, which indicates further precipitation during the diagenesis. The petrographic observation result has also given the nomenclature to this unit, grainstone. 


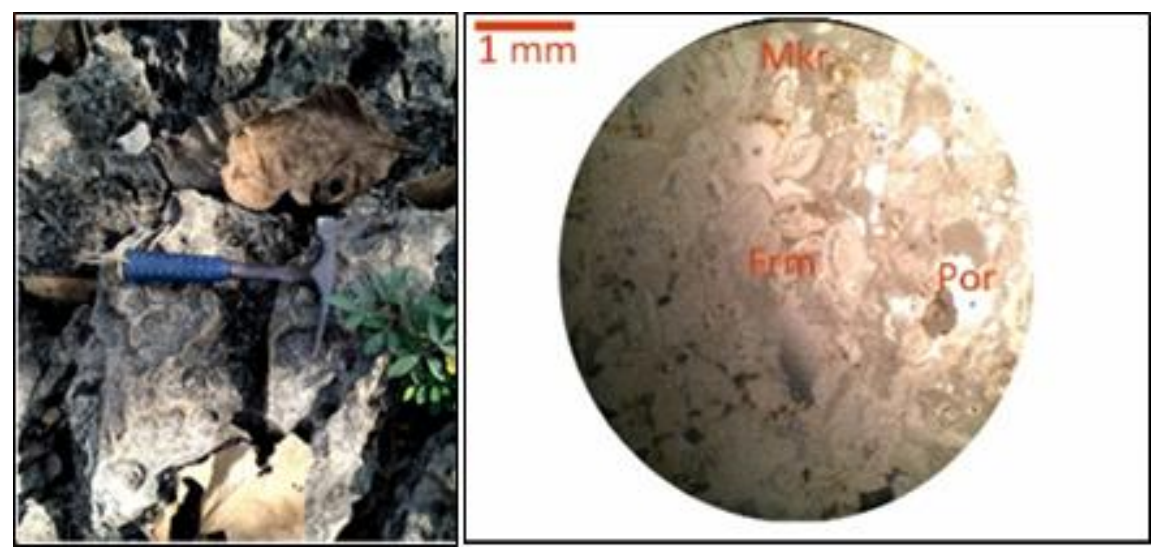

Figure 2. Outcrop of Rudstone Unit (left photo) and the petrographic view (right photo) that shows the occurrence of foraminifera (Frm), micrite (Mkr), and the porosity (Por).

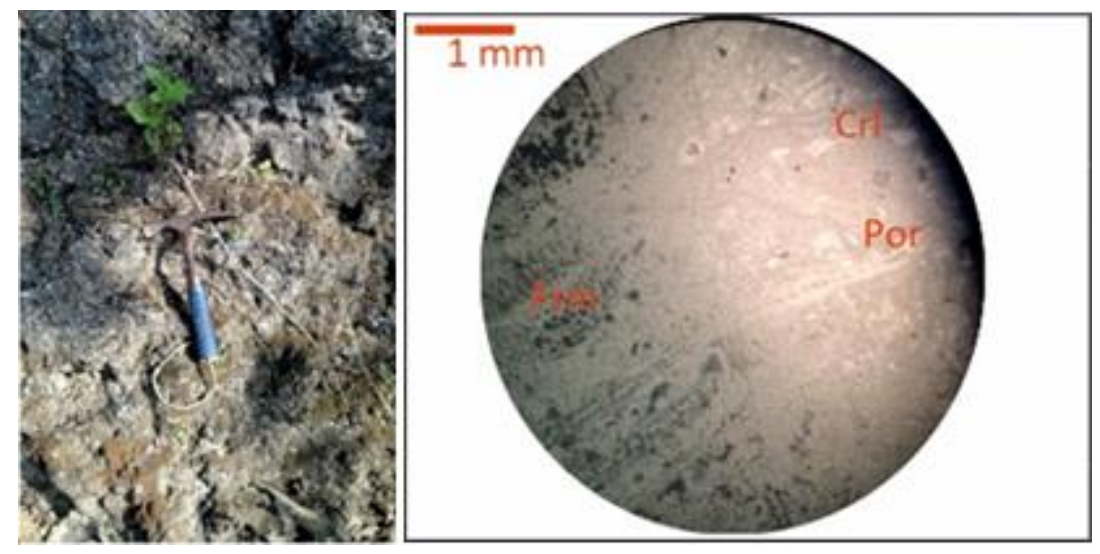

Figure 3. Outcrop of Grainstone Unit (left photo) and the petrographic view (right photo) that shows the occurrence of foraminifera (Frm), coralgal (Crl), and the porosity (Por).

The existence of both lithofacies on the surface has become the main cause that formed the karst morphology in the research area. The karst morphology is clearly pictured from the digital elevation model (DEM) map. On the northern part is more of a karst hills morphology, while on the southern part has turned into an area with a more gentle slope (Figure 4). 


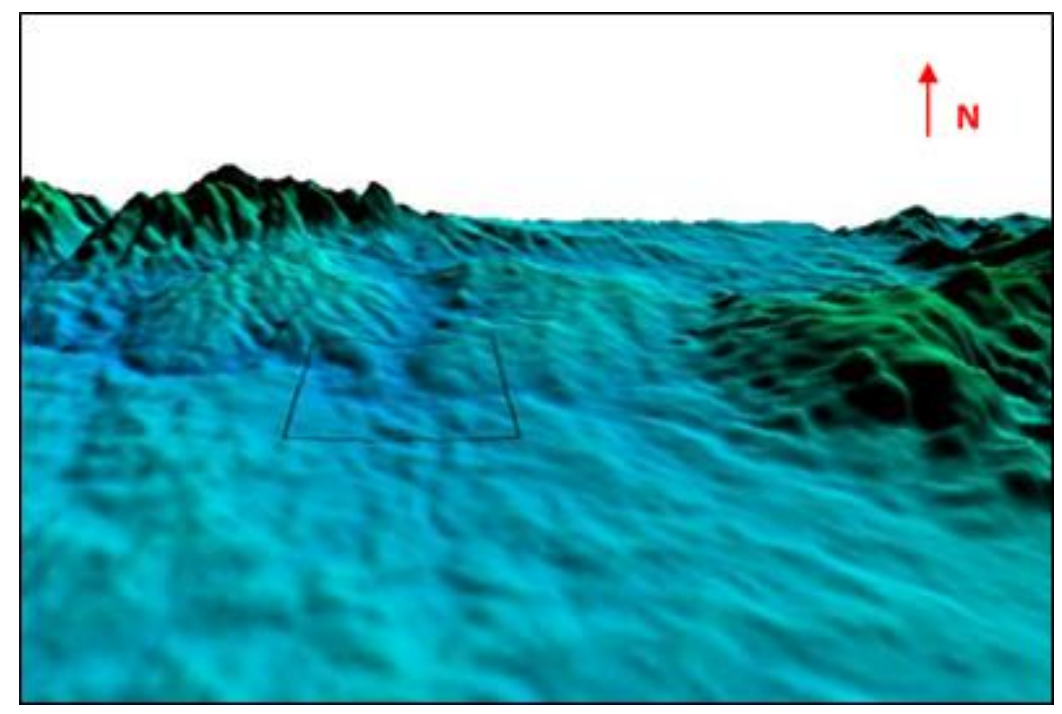

Figure 4. the morphology of karst landform that built the area of Pindul Cave and its surrounding. The box shows the coverage of the field observation.

\section{Geohazard Risk of Pindul Cave}

The analysis is conducted by considering only to the geohazard that most likely happened and gave impact to Pindul Cave. The geohazards include floods, landslides, earthquakes, volcanic eruptions, and tsunami.

1. Flood. The record of flood that happened in 2016 within the Pindul Cave area has become the consideration to score the Likelihood parameter of this geohazard as category C. The flood occurred when the rainfall rate is constantly $>200 \mathrm{~mm}$ about one hour which also caused the heavy overflow from within the cave (Nurkholis, 2016). In terms of the Consequences parameter, it is categorized into 3 and 4 because victims of the flood will need medical treatment, the disfunction of body parts in a short period of time, and also financial loss. Hence, the level of risk of floods will have significant to extreme risk ( $\mathrm{S}$ to $\mathrm{E}$ ) in Pindul Cave. The consequence can be reduced by applying an early warning system that sends an alert when the water level inside the cave is too high and kept rising, so the management shall close the activity when such condition is met.

2. Landslide. The northern part of the research area is karst hills, which means that the area has high-angle slope. The rocks at the surface is subject to weathering. These conditions are the main variables that can trigger landslide. Some of these areas are even transformed into public facility, for example a parking lot (Figure 5). The Likelihood of landslides to happened in Pindul Cave is categorized into D, where the event may happen in certain circumstances but with very low probability. The Consequences was categorized into level 4 (major) and 5 (catastrophic), because the event may cause death, total disfunction body parts, and high financial loss. Moreover, if there is no early warning, some tourists might happen to be inside the cave and got trapped because the cave collapsed. Thus, the risk level of landslide towards Pindul Cave is categorized into significant to extreme risk (S to E). In order to minimize the Likelihood, the management should apply engineering, such as grouting and installing gabions.

3. Earthquake. Southern Java, where Pindul Cave is located, is well known for its high seismic activity due to the close distance towards the subduction zone between the Indian Oceanic Plate and Eurasian Plate. This condition shows that the Likelihood of an earthquake in Pindul Cave area might happen in any kind of circumstances, that can 
be categorized as likely (B). The Consequences of this geohazard is categorized into level 4 (major) and 5 (catastrophic), because the casualty is high moreover there are no early warning for this hazard that causes a bigger problem when it comes to alert the tourists that are still inside the cave. Thus, the level of risk of earthquake in Pindul Cave is categorized as extreme risk (E). In order to reduce the consequences, it is important to design a quick evacuation whenever the hazard happened, by educating both the staff and the tourists in advance.

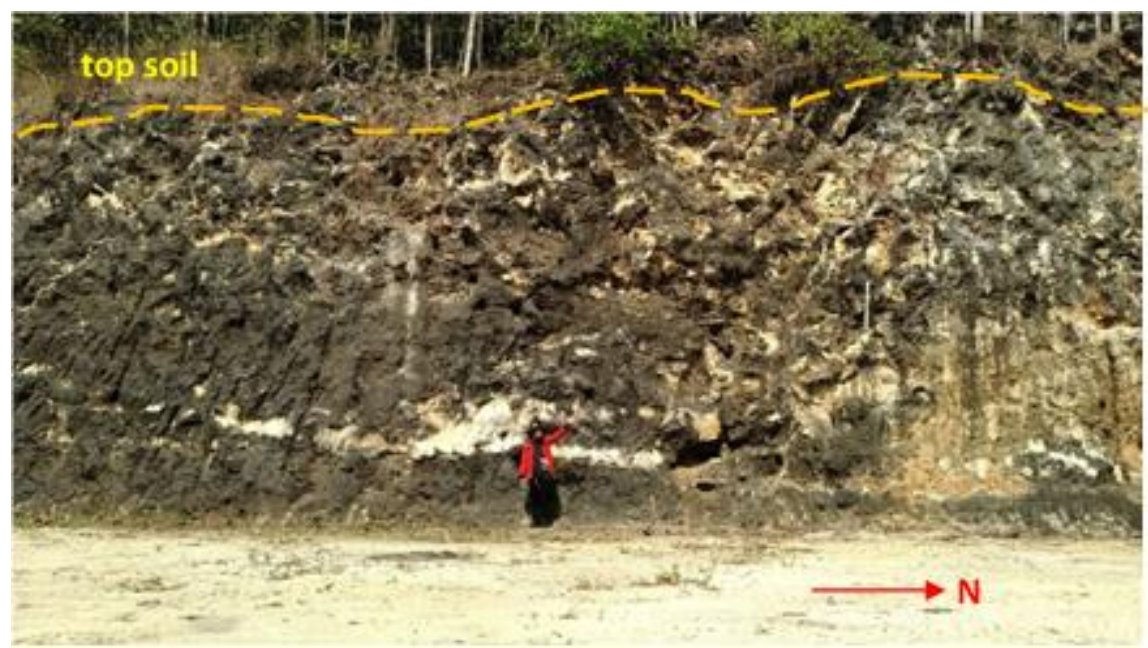

Figure 5. The parking lot in Pindul Cave provided for the tourists is located aside from a steep slope with no engineering that can support the slope stability.

Tabel 3. List of geohazard that can give impact to Pindul Cave with the likelihood parameter based on standards New Zealand (2004)

\begin{tabular}{lll}
\hline Level & Likelihood & $\begin{array}{l}\text { Geohazard that can give impact to Pindul } \\
\text { Cave }\end{array}$ \\
\hline A & $\begin{array}{l}\text { Almost certain- the event will certainly happen in } \\
\text { any kind of condition }\end{array}$ & - \\
B & $\begin{array}{l}\text { Likely- the event will probably happen in almost } \\
\text { any kind of condition }\end{array}$ & Earthquake, volcanic eruption, tsunami \\
C $\quad \begin{array}{l}\text { Moderate- the event will probably happen } \\
\text { conditionally }\end{array}$ & Flood \\
D $\quad \begin{array}{l}\text { Unlikely- the event low probability to happen } \\
\text { conditionally. }\end{array}$ & Landslide \\
E & $\begin{array}{l}\text { Rare- the event will probably happen specific } \\
\text { condition/ extraordinary/ after years from the last } \\
\text { event. }\end{array}$ & -
\end{tabular}


Tabel 4. List of geohazard that can give impact to Pindul Cave with consequence parameter based on standards New Zealand (2004)

\begin{tabular}{lll}
\hline Level & Criteria & $\begin{array}{l}\text { Geohazard that can give impact to Pindul } \\
\text { Cave }\end{array}$ \\
\hline 1 & $\begin{array}{l}\text { Insignificant- no injury, minor financial lost } \\
2\end{array}$ & $\begin{array}{l}\text { Minor- the injuries can be treated by first aid kit, } \\
\text { average financial lost }\end{array}$ \\
$\begin{array}{l}\text { Moderate- the injuries require medical treatment } \\
\text { and result in temporary loss of working days/ loss } \\
\text { of limb function, substantial material loss. }\end{array}$ & Flood \\
\hline $\begin{array}{l}\text { Major- Injuries that result in total disability/ loss of } \\
\text { bodily functions, not running the production } \\
\text { process, large material losses. }\end{array}$ & Flood, landslide, earthquake, tsunami \\
& $\begin{array}{l}\text { Catastrophe- Cause of death, very large material } \\
\text { loss. }\end{array}$ & Landslide, earthquake, \\
\hline
\end{tabular}

4. Volcanic eruption. The distance between the Pindul Cave and Mount Merapi is $47 \mathrm{~km}$ (on map view). This relatively close distance means that the volcanic eruption still has the slightest probability to cause impact to Pindul Cave area. Due to the Mount Merapi activity, the Likelihood of a volcanic eruption within Pindul Cave area is categorized as likely (B), means that the event may happen repetitively and gradually in any kind of condition. But, the Consequences is on level 1 or Insignificant, considering that the impact of volcanic eruption may not cause casualty nor financial loss to Pindul Cave. Hence, the level of risk of volcanic eruption is moderate $(\mathrm{M})$, where the management still needs to provide a first aid kit for mild casualty.

5. Tsunami. The tectonic setting of the Pindul Cave area not only causes high intensity of seismic activity, but most likely trigger a tsunami. This condition has made the Likelihood of tsunami to give impact to Pindul Cave is likely (B). As the Consequences caused by this geohazard in Pindul Cave is major (level 4). Thus, the level of risk caused by the tsunami is extreme risk (E). It is necessary to have an integrated early warning system of tsunami, so the mitigation will reduce the consequences of the tsunami geohazard.

\section{Conclusion}

Pindul Cave is a geosite in karst landform and has underwater stream, which is beneficial to upgrade the geotourism in it by providing tubing activity. The fact that all the arrived tourists will enter the 198.59 long cave, there are risks of geohazards that accompany. The risk level of the flood is extreme, that the management is highly encouraged to have a flood early warning system. The risk level of the landslide is significant to extreme, where the management should install gabions or do grouting to the slopes in the geosite. The risk level of earthquake is extreme, so the management must design a quick evacuation program to minimize the consequences. The risk level of tsunami is extreme even though the Likelihood is low, so the management should connect to the tsunami early warning system. The least level of risk comes from the volcanic eruption.

\section{Acknowledgements}

The authors would like to thank Pindul Cave for permission to collect the data inside the site and also the Faculty of Engineering Universitas Diponegoro for the research funding. 


\section{References}

Dinas Pariwisata DIY (2015). Statistik Kepariwisataan 2015. Bantul: Dinas Pariwisata Daerah Istimewa Yogyakarta. Dinas Pariwisata DIY (2016). Statistik Kepariwisataan 2016. Bantul: Dinas Pariwisata Daerah Istimewa Yogyakarta. Dinas Pariwisata DIY (2017). Statistik Kepariwisataan 2017. Bantul: Dinas Pariwisata Daerah Istimewa Yogyakarta. Dinas Pariwisata DIY (2018). Statistik Kepariwisataan 2018. Bantul: Dinas Pariwisata Daerah Istimewa Yogyakarta. Dinas Pariwisata DIY (2019). Statistik Kepariwisataan 2019. Bantul: Dinas Pariwisata Daerah Istimewa Yogyakarta. Dowling, R.K. (2011). Geotourism's Global Growth. Geoheritage, 3(1), 1-13.

Kubaliková, L. (2013). Geomorphosite assessment for geotourism purposes. Czech Journal of Tourism, 2, 80-104.

Nurkholis, A. (2016). Menuju Pariwisata Tangguh Bencana Melalui Analisis Hidrografi Banjir di Sistem Karst Goa Pindul, Kabupaten Gunungkidul. Proceeding UI Youth Environmental Action 2016.

Parno (2018). Gunung Sewu Unesco Geopark. Jakarta: Badan Pengembangan dan Pembinaan Bahasa Kementerian Pendidikan dan Kebudayaan.

Pereira, P., Pereira, D., Caetano Alves, M.I. (2007). Geomorphosite assessment in montesinho natural park (Portugal). Geographica Helvetica, 62(3), 159-168.

Pralong, J.P., Reynard, E. (2005). A proposal for a classification of geomorphological sites depending on their tourist value. Il Quaternario, 18(1), 315-321.

Rosana, M.F., Hardiyono, A., Yuningsih, E.T., Syafrie, I., Ikhram, R., Agusta, R. (2016). Exploring Geodiversity of Southwest Sukabumi for Ciletuh-Palabuhanratu Geopark. Proceedings Geosea XIV and 45th IAGI Annual Convention 2016, $151-154$

Standards New Zealand (2004). Risk Management Guidelines: companion to AS/NZS 4360:2004, Standards Australia/Standards New Zealand. Sydney, NSW : Standards Australia ; Wellington, N.Z. : Standards New Zealand.

Suyono, H. (2019). Ayo Lihat Goa Pindul yang dikelola BUMDes Maju Mandiri Desa Bejiharjo dengan Sukses. Gemari : Yogyakarta. 